\title{
MENINGKATKAN TANGGUNG JAWAB DAN HASIL BELAJAR SISWA MELALUI PENGGUNAAN E-MODULE AKUNTANSI TERINTEGRASI NILAI KARAKTER
}

\author{
Destri Sambara Sitorus, Universitas Kristen Satya Wacana \\ destri.sambara@uksw.edu
}

\begin{abstract}
ABSTRAK
Penguatan Pendidikan Karakter (PPK) yang dicanangkan pemerintah sebagai salah satu usaha untuk menciptakan peserta didik berkarakter baik, hal ini berarti proses pembelajaran juga memuat nilai-nilai karakter yang relevan dengan karakteristik materi pembelajaran serta kebutuhan di masyarakat. Proses internalisasi nilai-nilai karakter dapat dibantu dengan media pembelajaran seperti e-module. Penelitian ini bertujuan untuk menguji keefektifan e-module akuntansi terintegrasi nilai karakter untuk meningkatkan tanggung jawab dan hasil belajar siswa Sekolah Menegah Kejuruan (SMK). Penelitian ini merupakan penelitian kuasi eksperimen, data dikumpulkan dengan menggunakan angket dan tes. Data mengenai tanggung jawab siswa diperoleh melalui angket dan data mengenai hasil belajar siswa diperoleh melalui tes. Data mengenai tanggung jawab siswa dianalisis secara deskriptif naratif dan data hasil belajar siswa dianalisis menggunakan uji independent sample t-test. Hasil analisis angket menunjukkan tingkat tanggung jawab siswa kelas eksperimen berada pada kategori sangat baik dan tingkat tanggung jawab siswa kelas kontrol berada pada kategori baik. Penggunaan e-module akuntansi terintegrasi nilai karakter efektif untuk meningkatkan tanggung jawab dan hasil belajar siswa.
\end{abstract}

Kata Kunci: E-module, Tanggung Jawab, Hasil Belajar, Karakter.

\section{ABSTRACT}

Strengthening Character Education (PPK) launched by the government as an effort to create good character students, this means the learning process also contains character values that are deemed necessary and relevant to the characteristics of learning materials and needs in the community. The process of internalizing character values can be assisted with learning media such as e-modules. This study aims to test the effectiveness of the integrated accounting e-module of character values to increase the responsibilities and learning outcomes of Vocational High School (SMK) students. This research is a quasi-experimental study, data were collected using questionnaires and tests. Data regarding student responsibilities was obtained through a questionnaire and data regarding student learning outcomes were obtained through tests. Data regarding student responsibilities were analyzed descriptively narratively and data on student learning outcomes were analyzed using the independent sample t-test. The results of the questionnaire analysis showed that the level of 
responsibility of the experimental class students was in the very good category and the level of responsibility of the control class students was in a good category. The results obtained are significant differences in learning outcomes between the experimental class and the control class. Using an integrated e-module of accounting character values is effective for increasing student responsibility and learning outcomes.

Keywords: E-Module, Responsibility, Learning Outcome, Character.

\section{PENDAHULUAN}

Sekolah Menengah Kejuruan (SMK) merupakan sebuah sarana persiapan bagi siswa untuk memasuki dunia kerja (The UNESCO International Bureau of Education, 2013). SMK memiliki banyak program keahlian yang disesuaikan dengan kebutuhan dunia kerja dan masyarakat. Kurikulum SMK dibuat sedemikian rupa agar para peserta didik siap untuk terjun langsung pada dunia kerja setelah mereka menyelesaikan pendidikannya. Hal ini dilakukan agar peserta didik tidak mengalami kesulitan saat memasuki dunia kerja dan dapat mentransferkan ilmu serta keahlian kerja yang diperoleh selama duduk di bangku SMK. Namun demikian, data Badan Pusat Statistik (BPS) pada bulan Februari 2019 menunjukkan bahwa tingkat pengangguran terbuka dari SMK yaitu sebesar $8,63 \%$ dan merupakan yang tertinggi diantara tingkat pendidikan lainnya. Data BPS tahun 2018 juga masih menunjukkan hal yang sama, yaitu lulusan SMK merupakan penyumbang tertinggi pengangguran terbuka yaitu sebesar 8,92\%. Salah satu penyebab hal tersebut bisa terjadi adalah ketidakcocokan kompetensi yang dimiliki lulusan SMK dengan kualifikasi yang dibutuhkan oleh dunia kerja dan rendahnya kompetensi yang dimiliki (Supriyadi, Zamtinah, Soenarto, \& Hatmojo, 2019). Selain itu beberapa menduga bahwa kurikulum yang diterapkan belum mampu memenuhi kebutuhan dunia kerja, perkembangan teknologi, dan inovasi di bidang pendidikan (Larocque, 2015).

Dalam hal bekerja ada beberapa aspek yang perlu diperhatikan selain keahlian dan pengetahuan akan bidang pekerjaan yang ditekuni, yaitu terkait etika atau sikap dalam bekerja. (Spisak, 2015) menyatakan bahwa sikap apatis, datang terlambat, kemampuan beradaptasi yang rendah, perilaku dan komunikasi yang tidak pantas dapat menyebabkan seseorang kehilangan pekerjaannya. Karakter dimaknai sebagai cara berpikir dan berperilaku yang khas tiap individu untuk hidup dan bekerjasama, baik dalam lingkungan keluarga, masyarakat, bangsa dan negara (Zamroni, 2011). Individu yang berkarakter baik adalah individu yang dapat membuat keputusan dan sikap mempertanggungjawabkan setiap akibat dari keputusannya. Berkaitan dengan hal tersebut diperlukan sebuah program pendidikan yang di dalamnya memuat pendidikan karakter, hal ini diperlukan sebagai sebuah upaya untuk menciptakan individu yang berkarakter baik. Pendidikan karakter dapat diartikan sebagai sebuah proses pengembangan nilai dan perilaku sehingga individu dapat berinteraksi dengan baik di masyarakat (Bialik, Bogan, Fadel, \& Horvatova, 2015). Proses pendidikan karakter di dalam sekolah dapat dilakukan melalui kegiatan pembelajaran, kegiatan ekstrakulikuler, maupun melalui peraturan-peraturan sekolah. 
Kurikulum 2013 yang saat ini diterapkan pada seluruh jenjang pendidikan memasukkan nilai-nilai karakter pada setiap materi pembelajaran sebagai sebuah upaya untuk menanamkan karakter pada peserta didik. Nilainilai karakter ini disesuaikan dengan karakteristik materi pelajaran, sehingga terdapat kesinambungan antara keduanya dan siswa dapat mengaitkan nilainilai tersebut dengan persoalan sehari-hari (Gholar, 2004). Pengintegrasian pendidikan karakter pada materi pembelajaran menuntut adanya inovasi pada media-media pembelajaran untuk juga memuat pendidikan karakter di dalamnya sehingga kegiatan pembelajaran berjalan dengan baik dan tujuan pembelajaran dapat tercapai. Nugrahani (2017) menunjukkan bahwa bahan ajar yang terintegrasi nilai karakter terbukti mampu meningkatkan karakter siswa terutama untuk karakter kepercayaan diri, kepedulian, dan nasionalisme.

Pengintegrasian pendidikan karakter pada mata pelajaran akuntansi terdapat nilai-nilai karakter yang menjadi ciri dari pembelajaran akuntansi seperti nilai kejujuran dalam proses pencatatan sampai dengan pelaporan keuangan, nilai ketelitian karena dalam mengerjakan sebuah pencatatan akuntansi diperlukan ketelitain agar proses pencatatan benar, nilai kerja keras dan tanggung jawab dalam menyelesaikan proses pencatatan akuntansi dari awal sampai akhir. Nilai-nilai tersebut dapat ditanamkan pada diri siswa melalui kegiatan pembelajaran akuntansi dan penggunaan media pembelajaran akuntansi yang terintegrasi nilai karakter. Penelitian oleh Jaya, Sadia, dan Arnyana (2014) menunjukkan bahwa perangkat pembelajaran bermuatan pendidikan karakter mampu meningkatkan karakter dan hasil belajar siswa. Sejalan dengan itu, Kurniawan, Sarwanto, dan Cari (2013) juga menunjukkan hasil bahwa modul yang terintegrasi dengan nilai karakter dapat meningkatkan sisi afektif siswa secara signifikan. E-module terintegrasi nilai karakter menjadi salah satu solusi untuk menginternalisasikan nilai-niilai karakter dengan penyampaian yang menyenangkan disertai gambar, video, serta audio yang dapat membantu siswa untuk lebih tertarik menggunakan e-module dan membantu siswa dalam memahami materi pelajaran yang terdapat di dalamnya.

\section{METODE PENELITIAN}

Penelitian ini merupakan penelitian kuasi eksperimen yang dilakukan di SMK Negeri 6 Surakarta. Dipilihnya sekolah ini atas dasar sekolah telah menerapkan kurikulum 2013 yang mana kurikulum ini tidak hanya fokus pada pembentukan kognitif siswa tetapi juga membentuk afektif atau sikap serta psikomotorik atau keterampilan siswa. Selain itu, sekolah ini juga memiliki laboratorium komputer yang lengkap sehingga siswa dapat menggunakan $e$ module dengan bebas dan tanpa batas.

Populasi pada penelitian ini adalah siswa kelas X SMK Negeri 6 Surakarta dengan sampel penelitian adalah siswa kelas X Akuntansi. Pemilihan sampel dengan menggunakan teknik purposive sampling. Sampel dipilih berdasarkan kriteria yaitu siswa mendapatkan mata pelajaran akuntansi dan materi yang terdapat di dalam e-module belum pernah dipelajari atau disampaikan guru di dalam kelas. Penelitian dilakukan pada kelas X Akuntansi 2 yang merupakan kelas kontrol dan X Akuntansi 3 yang merupakan kelas eksperimen. Masing-masing kelas terdiri dari 32 orang siswa. Pada kelas 
kontrol proses pembelajaran berjalan normal seperti biasanya dengan menggunakan buku teks, sedangkan pada kelas eksperimen proses pembelajaran menggunakan e-module yang terintegrasi nilai karakter.

Data dikumpulkan dengan menggunakan angket dan tes.Angket digunakan untuk mengukur sikap tanggung jawab siswa dan dilakukan dengan penilaian teman sejawat. Angket terdiri dari 15 pertanyaan yang disusun berdasarkan indikator karakter tanggung jawab seperti mengerjakan pekerjaan yang menjadi kewajibannya, mengumpulkan tugas tepat waktu, mengerjakan tugas sampai selesai, mengerjakan kewajiban dengan serius, tidak asal-asalan, peduli pada lingkungan, meminjam barang dan mengembalikannya, tidak ingkar janji, melaksanakan sanksi atas kesalahan yang diperbuat (Widayanti, 2009). Penilaian angket menggunakan skala Likert dengan rentan skor 1 sampai 4. Pemilihan skala Likert dengan 4 skor ini didasarkan pada pertimbangan mudah dipahami responden (Sugiyono, 2009) serta untuk menghindari responden memilih jawaban "netral".

Hasil angket selanjutnya dikonversikan menjadi data kualitatif untuk melihat tingkat ketercapaian karakter tanggung jawab pada diri siswa. Konversi data kuantitatif ke dalam data kualitatif menggunakan skala kualifikasi yang disajikan dalam Tabel 1.

Tabel 1. Konversi Tingkat Ketercapaian Karakter Tanggung Jawab

\begin{tabular}{cc}
\hline Tingkat & Kualifikasi \\
Ketercapaian & \\
\hline $90 \%-100 \%$ & Sangat Baik \\
$75 \%-89 \%$ & Baik \\
$65 \%-74 \%$ & Sedang \\
$55 \%-64 \%$ & Kurang \\
$0 \%-54 \%$ & Sangat Kurang \\
\hline
\end{tabular}

Sumber: Agung, 2010

Tes dilakukan untuk mengukur pemahaman siswa akan materi pembelajaran, yaitu laporan keuangan perusahaan jasa. Langkah-langkah yang dilakukan untuk mengetahui keefektifan e-module dalam meningkatkan hasil belajar siswa adalah dengan melakukan pretestdan posttest. Data hasil pretestdan posttestselanjutnya diuji normalitas dan homogenitasnya. Uji normalitas menggunakan uji Kolmogrov-Smirnov dengan $\alpha=0,05$ dan uji homogenitas menggunakan uji Levene dengan $\alpha=0,05$. Apabila hasil uji menunjukkan bahwa data normal dan homogen, selanjutnya dilakukan uji $\mathrm{t}$ dengan taraf signifikansi 0,05 untuk melihat perbedaan antara dua kelas tersebut.

\section{HASIL PENELITIAN DAN PEMBAHASAN}

Angket berisi 15 pertanyaan yang disusun berdasarkan indikator karakter tanggung jawab. Pertanyaan yang terdapat pada angket seperti apakah siswa mengerjkan tugas yang diberikan pada guru, apakah siswa mengikuti Standar Akuntansi Keuangan (SAK) saat menyusun laporan keuangan, apakah siswa bersungguh-sungguh dalam belajar dan mengerjakan tugas, apakah siswa 
memprioritaskan belajar dari pada bermain atau bersenang-senang, serta mengakui kesalahan yang diperbuatnya. Angket diberikan di awal petemuan untuk melihat karakter awal siswa serta di akhir pertemuan untuk melihat apakah ada perubahan karakter pada diri siswa.

Angket penilaian awal karakter tanggung jawab menunjukkan bahwa rata-rata siswa pada kelas kontrol dan eksperimen berada dalam kategori baik, artinya siswa sudah tahu apa yang dimaksud dengan tanggung jawab dan sudah melakukan tanggung jawabnya sebagai seorang pelajar dengan baik, namun hal ini masih dapat dioptimalkan lagi agar karakter tanggung jawab dapat tertanam dan menjadi kebiasaan pada diri siswa.

Setelah dilakukan penilaian awal karakter tanggung jawab dan hasil angket menunjukkan bahwa rata-rata siswa pada kelas kontrol dan eksperimen berada pada kategori yang sama yaitu kategori baik, maka selanjutnya masingmasing kelas diberi perlakuan yang berbeda saat proses pembelajaran akuntansi. Kelas kontrol menggunakan buku teks akuntansi dan power point sedangkan kelas ekperimen menggunakan e-module akuntansi terintegrasi nilai karakter. Di akhir pertemuan dilakukan peer assessment dengan memberikan angket pada siswa. Hasil angket menunjukkan bahwa siswa pada kelas eksperimen mengalami peningkatan menjadi kategori sangat baik, sedangkan pada kelas kontrol tetap pada kategori baik. Secara lebih detail hasil angket penilaian awal dan penilaian akhir kelas kontrol dan eksperimen disajikan pada Tabel 2.

Tabel 2. Rekapitulasi Penilaian Karakter Tanggung Jawab Kelas Eksperimen dan Kontrol

\begin{tabular}{ccccc}
\hline & \multicolumn{2}{c}{ Kelas Eksperimen } & \multicolumn{2}{c}{ Kelas Kontrol } \\
& Rata-Rata & Kategori & Rata-Rata & Kategori \\
\hline Penilaian awal & $83,40 \%$ & Baik & $77,89 \%$ & Baik \\
Penilaian akhir & $92,76 \%$ & Sangat Baik & $77,96 \%$ & Baik \\
\hline
\end{tabular}

Uji normalitas dilakukan untuk mengetahui apakah data yang digunakan dalam penelitian terdistribusi normal atau tidak. Uji normalitas dilakukan dengan menggunakan uji Kolmogrov-Smirnov dengan $\alpha=0,05$. Dapat dilihat pada Tabel 3. bahwa nilai signifikansi uji normalitas data pretest dan posttest di kelas eksperimen dan kontrol lebih dari $\alpha(0,2>0,05)$. Ini menunjukkan bahwa nilai tes yang digunakan untuk mengukur pemahaman siswa akan materi laporan keuangan perusahaan jasa, antara kelas eksperimen dan kontrol terdistribusi normal, baik itu nilai pretest atau posttest.

Tabel 3. Uji Normalitas Data Pretest dan Posttest

\begin{tabular}{ccccc}
\hline & \multicolumn{2}{c}{ Pretest } & \multicolumn{2}{c}{ Posttest } \\
\cline { 2 - 5 } & Eksperimen & Kontrol & Eksperimen & Kontrol \\
\hline N & 32 & 32 & 32 & 32 \\
Sig & 0,2 & 0,2 & 0,2 & 0,2 \\
\hline
\end{tabular}

Uji homogenitas dilakukan untuk mengetahui apakah data yang diperoleh memiliki varian homogen atau tidak. Metode yang digunakan adalah melalui Tes Levene dengan $\alpha=0,05$. Berdasarkan Tabel 4, dapat dilihat bahwa nilai 
signifikansi Uji Levene untuk data pretest adalah 0,535. Nilai tersebut lebih besar dari 0,05 sehingga dapat dikatakan bahwa nilai pretest antara kelas eksperimen dan kontrol memiliki varian yang homogen. Nilai signifikansi dari data posttest adalah 0,975 sehingga dapat disimpulkan bahwa nilai posttest antara kelas eksperimen dan kontrol memiliki varian yang homogen.

Tabel 4. Uji Homogenitas Data Pretest dan Posttest

\begin{tabular}{ccccc}
\hline Data & Levene Statistic & df 1 & df 2 & Sig \\
\hline Pretest & 0,389 & 1 & 62 & 0,535 \\
Posttest & 0,001 & 1 & 62 & 0,975 \\
\hline
\end{tabular}

Uji keefektifan sekaligus uji hipotesis dalam penelitian ini menggunakan uji-t dengan tingkat $a=0,05$. Pengujian hipotesis dengan uji t digunakan untuk menguji keefektifan e-module akuntansi terintegrasi nilai karakter. Nilai pretest dan posttest siswa disajikan dalam 5 di bawah ini.

Tabel 5. Nilai Pretest dan Posttest

\begin{tabular}{cccccc}
\hline Data & Kelas & N & Mean & $\begin{array}{c}\text { Std. } \\
\text { Deviation }\end{array}$ & $\begin{array}{c}\text { Std. Error } \\
\text { Mean }\end{array}$ \\
\hline Pretest & Eksperimen & 32 & 62,97 & 10,149 & 1,794 \\
& Kontrol & 32 & 66,41 & 9,179 & 1,623 \\
Posttest & Eksperimen & 32 & 81,25 & 8,424 & 1,489 \\
& Kontrol & 32 & 75,94 & 8,370 & 1,480 \\
\hline
\end{tabular}

Berdasarkan Tabel 5 dapat dilihat bahwa rata-rata pretest kelas eksperimen sebesar 62,97 dan kelas kontrol sebesar 66,41. Hal ini menunjukkan bahwa rata-rata hasil belajar kelas kontrol lebih tinggi dari pada kelas eksperimen. Namun hasil ini perlu diuji lebih lanjut untuk melihat apakah perbedaan tersebut merupakan perbedaan yang signifikan atau tidak, maka dilakukan uji Independent Sample Test. Hasil uji Independent Sample Test disajikan pada Tabel 6 di bawah ini.

Tabel 6. Uji t-test data Pretest dan Posttest

\begin{tabular}{lccccccc}
\hline \multicolumn{1}{c}{$\begin{array}{c}\text { Levene's Test } \\
\text { for Equality of } \\
\text { Variances }\end{array}$} & \multicolumn{1}{c}{ t-test for Equality of Means } \\
\cline { 2 - 8 } & F & Sig & t & df & $\begin{array}{c}\text { Sig (2- } \\
\text { tailed) }\end{array}$ & $\begin{array}{c}\text { Mean } \\
\text { Difference }\end{array}$ & $\begin{array}{c}\text { Std. Error } \\
\text { Difference }\end{array}$ \\
\hline Pretest & 0,389 & 0,535 & 1,421 & 62 & 0,160 & 3,438 & 2,419 \\
Posttest & 0,001 & 0,975 & 2,531 & 62 & 0,014 & 5,313 & 2,099 \\
\hline
\end{tabular}

Berdasarkan tabel di atas dapat diketahui bahwa nilai signifikansi uji-t data pretest adalah 0,160 yang mana nilai tersebut lebih besar dari 0,05. Hal tersebut menunjukkan bahwa tidak ada perbedaan yang signifikan rata-rata hasil belajar antara kelas ekperimen dan kelas kontrol sebelum menggunakan e-module akuntansi terintegrasi nilai karakter. Setelah memastikan bahwa siswa kelas eksperimen dan kelas kontrol memiliki tingkat pemahaman yang sama, selanjutnya peneliti memberikan perlakuan yang berbeda antara kelas 
eksperimen dan kelas kontrol. Proses pembelajaran di kelas kontrol menggunakan buku teks akuntansi dan power point sedangkan kelas eksperimen menggunakan e-module akuntansi terintegrasi nilai karakter. Proses pembelajaran pada kelas eksperimen dan kelas kontrol berlangsung sebanyak 4 kali pertemuan, pada akhir pertemuan siswa diberikan tes untuk melihat sejauh mana pemahaman siswa akan materi yang telah diberikan. Tabel 5 menunjukkan bahwa rata-rata posttest kelas eksperimen sebesar 81,25 sedangkan kelas kontrol sebesar 75,94. Hal ini menunjukkan bahwa masingmasing kelas mengalami peningkatan dari hasil tes sebelumnya, dan juga menunjukkan bahwa rata-rata hasil belajar kelas eksperimen lebih tinggi dari pada kelas kontrol.

Sama seperti sebelumnya, untuk memastikan apakah perbedaan hasil belajar tersebut signifikan atau tidak, maka dilakukan uji Independent Sample Test. Berdasarkan Tabel 6 didapat nilai signifikansi data posttest sebesar 0,014 yang mana nilai tersebut kurang dari 0,05 . Hasil tersebut menujukkan bahwa kelas eksperimen lebih baik dari pada kelas kontrol dan menunjukkan bahwa terdapat perbedaan yang signifikan rata-rata hasil belajar antara kelas eksperimen dan kelas kontrol setelah menggunakan e-module akuntansi terintegrasi nilai karakter.

Penelitian ini dilakukan untuk melihat apakah penggunaan e-module akuntansi terintegrasi nilai karakter dapat meningkatkan tanggung jawab dan hasil belajar siswa. Penelitian ini dilakukan di SMK Negeri 6 Surakarta, subjek penelitian ini adalah siswa kelas X Akuntansi 2 sebagai kelas kontrol dan X Akuntansi 3 sebagai kelas eksperimen. Dalam penelitian ini, siswa di kelas eksperimen menggunakan e-module akuntansi terintegrasi nilai karakter dalam proses pembelajaran, sedangkan kelas kontrol menggunakan buku teks akuntansi dan power point.

Langkah pertama dalam penelitian ini adalah memberikan kuesioner kepada siswa mengenai karakter tanggung jawab. Karakter ini sesuai dengan karakteristik materi pembelajaran, dimana membuat laporan keuangan adalah sebuah bentuk pertanggung jawaban manajer terhadap pemilik perusahaan, selain itu di dalam mengerjakan laporan keuangan perusahaan harus disertai dengan rasa penuh tanggung jawab. Hasil kuesioner awal kelas eksperimen dan kelas kontrol yang disajikan pada tabel 2 menunjukkan bahwa rata-rata siswa berada pada kategori baik.

Pada kelas eksperimen, penggunaan e-module memfasilitasi siswa untuk dapat berlatih bersikap bertanggung jawab. Di dalam e-module terdapat video mengenai pentingnya memiliki sikap tanggung jawab baik dalam menyusun laporan keuangan maupun dalam kegiatan sehari-hari. Selain itu terdapat beberapa contoh kasus terkait dengan karakter tanggung jawab dan juga pertanyaan refleksi setelah siswa menonton video dan membaca contoh kasus sehingga siswa dapat menuliskan perasaan mereka dan bagaimana mereka harus bersikap agar dapat dipercaya. Dalam proses belajar, guru membiasakan siswa untuk menuliskan sumber data pada setiap tugas atau laporan yang dibuat, hal ini dimaksudkan agar siswa dapat mempertanggungjawabkan tugas yang dikerjakannya dengan mampu menunjukkan data yang diperolehnya.

Pada kelas kontrol yang tidak menggunakan e-module akuntansi terintegrasi nilai karakter, tingkat pencapaian karakter tanggungjawab termasuk 
dalam kategori baik. Pada proses pembelajarannya, siswa belajar seperti biasanya menggunakan buku teks serta power point. Media pembelajaran yang digunakan tidak memfasilitasi siswa untuk mempraktikkan nilai-nilai tanggung jawab sehingga siswa tidak mengetahui bagaimana pentingnya berperilaku bertanggung jawab, apa dampak yang akan diterima jika tidak siswa tidak mampu bertanggung jawab atas hal-hal yang dikerjakannya, manfaat yang diperoleh ketika siswa mampu bertanggung jawab, serta bagaimana untuk berperilaku bertanggung jawab.

Di akhir pertemuan siswa diberi kuesioner mengenai nilai tanggung jawab yang terkandung di dalam modul. Hasil kuesioner di kelas eksperimen menunjukkan bahwa setelah menggunakan e-module tingkat pencapaian tanggung jawab siswa meningkat dari kategori baik menjadi sangat baik. Hal ini menunjukkan bahwa siswa telah menunjukkan sikap tanggung jawab pada pembelajaran akuntansi berdasarkan indikator yang telah ditetapkan. (Liliasari, 2010) menyatakan bahwa karakter siswa dapat dibentuk melalui proses pembelajaran dengan catatan bahwa standar isi, standar proses, dan standar evaluasi harus terpenuhi sehingga tujuan pembelajaran dapat tercapai. Maka dapat dikatakan bahwa proses pembelajaran menggunakan e-module akuntansi terintegrasi nilai karakter telah memenuhi standar di atas sehingga tujuan pembelajaran yang ditetapkan dapat tercapai. Sejalan dengan hal tersebut, bahan ajar berbasis pendidikan karakter menjadi sarana untuk menerapkan kurikulum 2013 di dalam kelas. Respon siswa terhadap penggunaan bahan ajar tersebut, siswa merasa senang menggunakannya karena dapat menumbuhkan rasa percaya diri mereka, jiwa kompetitif namun tetap bisa menghargai satu dan lainnya (Maulida et al., 2015).

Penggunaan e-module akuntansi terintegrasi nilai karakter juga ingin melihat aspek pengetahuan siswa, apakah penggunaan e-module ini memudahkan siswa untuk memahami materi dan meningkatkan hasil belajar siswa. Tahapan yang dilakukan sama seperti ketika akan melihat perubahan karakter siswa, yaitu pertama-tama siswa diberikan pretest sebanyak 20 butir soal untuk melihat kemampuan awal siswa. Hasil pretest kemampuan kognitif siswa ditunjukkan dalam tabel 5 dengan nilai rata-rata kemampuan kognitif kelas eksperimen 62,97 dan rata-rata kemampuan kognitif kelas kontrol 66,41.

Setelah diketahui nilai rata-rata kelas eksperimen dan kelas kontrol dipastikan bahwa kedua kelas tersebut memiliki hasil belajar yang sama atau tidak terdapat perbedaan yang signifikan sehingga ke dua kelas dapat diberikan perlakuan yang berbeda dalam proses pembelajaran akuntansi. Proses pembelajaran kelas eksperimen dan kelas kontrol dilakukan sebanyak 4 kali tatap muka. Setelah pertemuan ke 4 selesai, kedua kelas diberikan posttest untuk mengukur apakah modul yang diterapkan efektif untuk meningkatkan hasil belajar. Data hasil posttest disajikan dalam pada tabel 5, dimana diketahui rata-rata hasil belajar kelas eksperimen adalah 81,25 dan kelas kontrol adalah 75,94 . Nilai tersebut menunjukkan bahwa nilai hasil belajar kelas eksperimen lebih tinggi dibandingkan dengan nilai hasil belajar kelas kontrol.

Data nilai hasil belajar dari kelas eksperimen dan kelas kontrol selanjutnya diuji untuk melihat keefektifannya dengan menggunakan uji Independent Sample Test untuk melihat apakah ada perbedaan hasil belajar antara kelas eksperimen dan kelas kontrol. Hasil uji keefektifan posttest 
terdapat pada tabel 6 yang menunjukkan bahwa nilai uji t signifikansi sebesar 0,014 . Dengan demikian maka ada perbedaan yang signifikan rata-rata hasil belajar peserta didik antara kelas eksperimen dan kelas kontrol atau hasil belajar peserta didik kelas eksperimen dan kelas kontrol adalah berbeda.

Data hasil posttest dalam tabel 5 yang menunjukkan rata-rata hasil belajar kelas eksperimen lebih tinggi dibandingkan dengan kelas kontrol dapat disandingkan dengan hasil uji keefektifan antara kedua kelas yang menunjukkan ada perbedaan. Penyandingan kedua hasil uji tersebut menunjukkan bahwa penggunaan e-module akuntansi terintegrasi nilai karakter efektif untuk meningkatkan hasil belajar siswa. Hal ini didukung dengan penelitian yang dilakukan oleh (Woo, 2011) bahwa modul elektronik lebih memuaskan dan lebih memperkaya pengalaman belajar siswa jika dibandingkan dengan modul cetak. Selain itu penggunaan e-module dalam pembelajaran sangat efektif meningkatkan kemampuan siswa dalam memahami materi pembelajaran (Scott, 2017)

Penelitian lain mengenai implementasi pendidikan karakter juga dilakukan oleh Garry Skaggs dan Nancy Bodenhorn (2006). Penelitian yang dilakukan Skaggs dan Bodenhorn ingin melihat hubungan antara implementasi pendidikan karakter terhadap perilaku siswa dan hasil belajarnya, namun hasil dari penelitian tersebut menunjukkan bahwa pendidikan karakter tidak berpengaruh signifikan terhadap prestasi belajar siswa. Nancy G. Harringtong, dkk (2001) dalam penelitiannya mengenai evaluasi pendidikan karakter pada siswa sekolah menengah di Amerika menunjukkan bahwa program pendidikan karakter yang diterapkan tidak berpengaruh secara konsisten terhadap perilaku siswa. Hasil dari kedua penelitian tersebut menunjukkan bahwa usaha untuk menanamkan pendidikan karakter tidak cukup dilakukan oleh guru saja, akan tetapi juga lingkungan juga memiliki peran yang penting untuk terjadinya pendidikan karakter. Agar proses pendidikan karakter dapat terlaksana dengan baik dan dapat mencapai tujuan yang diinginkan, maka sekolah harus berusaha untuk menciptakan lingkungan yang kondusif serta terpadu antara guru dan lingkungan sekolah, orang tua, serta lingkungan masyarakat. Selain itu juga peran kontrol sosial masyarakat serta evaluasi berkelanjutan perlu dilakukan untuk terus memantau perubahan tingkah laku siswa ke arah yang positif.

\section{SIMPULAN}

E-module akuntansi terintegrasi nilai karakter terbukti efektif dalam meningkatkan tanggung jawab dan hasil belajar siswa. Hasil penelitian menunjukkan bahwa terjadi peningkatan tanggung jawab siswa pada kelas eksperimen dari kategori baik menjadi kategori sangat baik, sedangkan pada kelas kontrol tidak terjadi peningkatan. Nilai signifikansi pada uji keefektifan kelas kontrol dan kelas eksperimen adalah $0,014<0,05$. Rata-rata hasil belajar siswa pada kelas eksperimen adalah 81,25 sedangkan pada kelas kontrol 75,94. Penggunaan e-module terintegrasi nilai karakter dapat menjadi solusi untuk menerapkan proses pembelajaran yang mendukung terlaksanakanya kurikulum 2013. Penggunaan e-module terintegrasi nilai karakter harus didesain sedemikian rupa serta dikombinasikan dengan strategi atau model 
pembelajaran yang tepat sehingga dapat mencapai tujuan pembelajaran serta terimplementasinya nilai-nilai karakter yang ditetapkan.

\section{DAFTAR RUJUKAN}

Bilaik, M., Bogan, M., Fadel, C., \& Horvatova, M. (2015). Character education for the 21st century: what should students learn? Boston, Massachusetts: Center for Curriculum Redesign.

Gholar, C. (2004). Character Education: Creating a Framework for Excellence. Urban Programs Resource Network.

Harrington, N.G., Giles, S.M., \& Hoyle, R.H. (2001). Evaluation of the all stars character education and problem behaviour prevention program: effects on mediator and outcome variables for middle school students. Health Education \& Behaviour, 28(50, 533-546.

Jaya, I.M., Sadia, I.W., Arnyana, I.B.P. (2014). Pengembangan perangkat pembelajaran biologi bermuatan pendidikan karakter dengan setting guide inquiry untuk meningkatkan karakter dan hasil belajar siswa SMP. E-Journal Program Pascasarjana Universitas Pendidikan Ganesa, 4, 112.

Kurniawan, H.E., Sarwanto \& Cari (2013). Pengembangan modul IPA SMP berbasis problem based learning terintegrasi pendidikan karakter pada materi getaran dan gelombang. Seminar Nasional Fisika dan Pendidikan Fisika, 38-59.

Larocque, N. I. A. (2015). Summary of Indonesia'S Education Sector Assessment. 05.

Liliasari, I. W. A. S. \&. (2010). Kompetensi Ipa Terintegrasi Melalui Pendekatan Keterampilan Proses Mahasiswa S-1 Pendidikan Ipa. Jurnal Cakrawala Pendidikan, 3(3), 353-364. https://doi.org/10.21831/cp.v3i3.363

Maulida, M., Wati, M., \& An'nur, S. (2015). Pengembangan Bahan Ajar Berbasis Pendidikan Karakter Dalam Mendukung Implementasi Kurikulum 2013. Berkala Ilmiah Pendidikan Fisika, 3(1), 11. https://doi.org/10.20527/bipf.v3i1.760

Nugrahani, F. (2017). The development of film-based literray materials which support character education. Cakrawala Pendidikan, 36(3), 472-486.

Scott, W. (2017). Evaluating the effectiveness of an online module for increasing financial literacy. Social Studies Research and Practice, 12(2), 154-167. https://doi.org/10.1108/SSRP-04-2017-0014 
Skaggs, G., \& Bodenhorn, N. (2006). Relationship between implementing character education, student behaviour, and student achievement. Journal of Advanced Academics, 18(1), 333-345.

Spisak, D. (2015). Soft Skills: The Foundation for Academic and Career Success Soft Skills. Career Education Review, September, 1-21.

Sugiyono. (2009). Metode Penelitian Pendidikan: Pendekatan Kuantitatif, Kualitatif, Dan R\&D. Alfabeta: Bandung.

Supriyadi, E., Zamtinah., Soenarto, S., Hatmojo, Y.I. (2019). A characterbased assessment model for vocational high schools. Cakrawala Pendidikan, 32(2), 269-281.

Widayanti, E.Y. (2009). Keefektifan Model Susan Loucks-Horsley untuk Pendidikan Karakter Melalui Pembelajaran Sains di Tingkat Sekolah Dasar. Yogyakarta: Universitas Negeri Yogyakarta.

Wilujeng, I., Setiawan, A., \& Liliasari. (2010). Kompetensi IPA terintegrasi melalui pendekatan keterampilan proses mahasiswa S-1 pendidikan IPA. Cakrawala Pendidikan, 3(3), 150-163.

Woo, T. K. (2011). Developing Quality Learning Materials for Effective Teaching and Learning in an ODL environment: Making the jump from print modules to online modules. Asian Association of Open Universities Journal, 6(1), 51-58. https://doi.org/10.1108/aaouj-06-01-2011-b006

Zamroni. (2011). Dinamika Peningkatan Mutu. Yogyakarta: Gavin Kalam Utama. 
